\title{
DEPENDENCE ON IMPORTS AS A THREAT TO INNOVATIVE DEVELOPMENT OF THE RUSSIAN MANUFACTURING SECTOR"
}

\section{Evgenii Yu. KHRUSTALEV ${ }^{\text {a, }}$, Andrei S. SLAVYANOV ${ }^{\mathrm{b}}$}

a Central Economics and Mathematics Institute, Russian Academy of Sciences (CEMI RAS),

Moscow, Russian Federation

stalev@cemi.rssi.ru

ORCID: not available

${ }^{\mathrm{b}}$ Bauman Moscow State Technical University (Bauman MSTU), Moscow, Russian Federation aslavianov@mail.ru

ORCID: not available

- Corresponding author

\section{Article history:}

Received 12 April 2018

Received in revised form 23 April 2018

Accepted 3 May 2018

Available online

28 June 2019

JEL: L64, O14, O25

Keywords: innovative technology, competitiveness, import substitution, State aid

\begin{abstract}
Subject The research investigates that the Russian economy became less dependent on foreign imports of materials, spare parts, software and equipment needed for scienceintensive production.

Objectives The article comprehensively studies the dependence of the Russian economy on imports, outlines proposals for making science-intensive enterprises less vulnerable to external factors.
\end{abstract}

Methods The research is based on a systems method and methods of economic analysis.

Results Having analyzed the dependence on imports, we revealed key types of negative factors posing technological threats to the innovative development of the national economy. They mainly arise in production management, creation of productive means, foreign imports of materials and components. The Russian machine building was found to be almost completely dependent on foreign high-precision mixed-use machines and respective components. The Russian radio-electronic industry lags behind the global technological progress, being yet unable to supply domestically produced electronic devices to the Russian enterprises. Some top priority enterprises have automated management systems which are run by foreign experts. The prevalence of foreign equipment, materials, devices, other components and software stems from the low demand of the Russian consumers. Due to some reasons, the Russian manufacturers have not yet been able to offer high quality products to the Russian consumers.

Conclusions and Relevance The import substitution program has not yet worked as it was supposed to. In certain cases, replication of foreign equipment even aggravates the situation, inhibiting the technological development and advancement. We propose demand stimulation measures by leasing the equipment, subsidizing manufacturing enterprises and consumption of national products. Finance of researches into technological equipment, materials and new generation technologies deserves a special mention.

(c) Publishing house FINANCE and CREDIT, 2018

The editor-in-charge of this article was Irina M. Vechkanova

The authorized translation by Irina M. Vechkanova

Please cite this article as: Khrustalev E.Yu., Slavyanov A.S. Dependence on Imports as a Threat to Innovative Development of the Russian Manufacturing Sector. Digest Finance, 2019, vol. 24, iss. 2, pp. 124 - 134.

https://doi.org/10.24891/df.24.2.124 


\section{Introduction}

Withstanding complicated economic relations worldwide, Russia and its survival will strongly depend on its economic development. In its Address to the Federal Assembly, Vladimir Putin, President of the Russian Federation, made a special mention about this issue, 'Technological lag and dependence translate into reduced security and economic opportunities of the country and, ultimately, the loss of its sovereignty'. In the Strategy for Russia's Innovative Development 2020, which was earlier proclaimed, the national government called for increasing Russia's share in global high-tech markets, such as nuclear energy, aircraft engineering, space activities, etc. ${ }^{2}$ Industrially advanced countries attempted to suppress the implementation of the Strategy.

Being integrated into the global financial and political system, which is controlled by the USA, European Union and their satellites, Russia's economy got in a kind of trap. In the 1990s, Russia chose the path of economic reforms, which triggered technological threats which still exist. The technological threats may substantially undermine the development of the national science-intensive sector. Such threats stem from Russia's vulnerability to external factors that arose in the recent fifteen years. Considering the nature of their effects, we subdivide the threats into the following classes:

- dependence on production management (the first class threats);

- dependence on manufacturing of production means (the second class threats);

\footnotetext{
For the source article, please refer to: Хрусталёв Е.Ю., Славянов А.С. Импортозависимость как угроза инновационному развитию отечественной промышленности. Экономический анализ: теория и практика. 2018. Т. 17. № 6. C. 1000-1113. URL: https://doi.org/10.24891/ea.17.6.1000

${ }^{1}$ Presidential Address to the Federal Assembly. URL: http://en.kremlin.ru/events/president/news/56957

${ }^{2}$ Strategy for Russia's Innovative Development 2020. URL: http://static.government.ru/media/files/4qRZEpm161xctpb1 56a3ibUMjILtn9oA.pdf (In Russ.)
}

- dependence on supply of materials and components (the third class threats).

\section{Production Management Threats (The First Class Threats)}

Foreign shareholders financially control the Russian enterprises. Such foreign investment helps manage production processes through restrictions under technological licenses, supplies of components, software, etc. What poses special threats is the installation of automated production management systems at strategically important enterprises. Such systems are a gate to confidential business information, allowing to control business operations.

ERP (Enterprise Resource Planning) is the most widely spread management program. It embodies the organizational strategy for integrating the production and technological operations, management of assets, manpower and tangibles [1]. Databases are a distinctive feature of ERP. They contain detailed information about the entity, counterparts, employees, equipment, finance and other assets. Such databases are stored in special applications (modules), i.e. finance, logistics, HR, etc. ERP is a product offered by foreign corporations, such as German's SAP (System Analysis and Program Development), Oracle, Microsoft (the USA), Baan (the Netherlands). SAP took the lead of this market niche globally in the 1990s and delivered their automated management systems in over 60 percent of transnational corporations [2].

In Russia, the IT market is dominated by $1 \mathrm{C}$ and Galaktika. As for foreign companies operating in the Russian market, SAP is the most prominent one. It delivered $\mathrm{R} / 3$ ERP to major Russian companies taking strategic positions in the Russian economy and governmental institutions and organizations. R\&D in SAP and other companies significantly amplified the scope of ERP. In the 1990s, ERP was mainly installed at industrial and trading enterprises. However, in the early 2000s, there were developed 
applications for power engineering, housing and utilities, telecommunications, governmental institutions, banks, insurance companies and non-profits ${ }^{3}$.

$\mathrm{R} / 3$ ERP requires customers to have special computer-assisted equipment, which would be capable of running the program. It includes presentation servers, servers for applications and databases ${ }^{4}$.

The system operates effectively only after the entire corporate data are uploaded, including characteristics of key technological and ancillary equipment, products, demand for materials, information on suppliers and consumers, employees' personal data, etc. As a rule, such manipulations are controlled by providers' specialists, who are certainly granted access to confidential information. Throughout the license term, the provider appoints an adviser coordinating the program at the customer's place, monitors the correctness of program operations, helps fix various issues arising from the external and internal environment, manages trouble shooting sessions, etc. Customers incur millions Rubles every year to maintain the program. The license fees depend on an array of functions and scope of the entity and may cost millions as well.

The Russia-based office of SAP serves major industrial enterprises, whose performance shapes the economy of regions and federal fiscal revenue. SAP installed its software at strategically important industrial and power engineering enterprises of Russia, such as Cherepovetsk Metallurgical Plant (Severstal Group), NLMK Group, OMK Group, KamAZ, Rosneft Oil Company, Kaluga Turbine Works (KTZ), Gazprom, LUKOIL, Rosatom, etc. In transport and communications, SAP cooperates Russian Railways, Aeroflot, MTS, Megafon, etc.

\footnotetext{
${ }^{3}$ Chang She-I., Gable Guy, Smythe Errol, Timbrell Greg. A Delphi Examination of Public Sector ERP Implementation Issues. Proceedings of the XXI International Conference on Information Systems (ICIS 2000 Proceedings). Atlanta, ACM, 2000, pp. 494-500.

${ }^{4}$ Galimow J., Buck-Emden R. SAP R/3 System: A Client/Server Technology. Addison Wesley Professional, 1996, 272 p.
}

Obviously, the information about operations of the civil sector, including transport, communications, trade, manufacturing are under total control of foreign software providers, thus posing a threat to the national economic security [3].

What makes the situation even worse is that foreign corporations specializing in management automation target at governmental authorities and the financial system of the country. SAP serves the Post of Russia, Pension Fund of the Russian Federation, Central Bank of Russia, Analytical Center for the Government of the Russian Federation, Ministry of Industry and Trade of the Russian Federation, Federal Tax Service. Sberbank, Ural Bank for Reconstruction and Development (UBRD), Promsvyazbank, AlfaInsurance, etc. are SAP's customers too. SAP's systems has been integrated in Tactical Missiles Corporation. In 2010, Russian Space Systems also chose to create the automated production management system on the basis of SAP ERP. The decision raises our concerns since the database will contain all the information about the company's contracts with the other entities of Roscosmos, which definitely puts at stake the security of strategic space projects.

Other foreign IT companies also deploy active promotion campaigns in the Russian markets. We should mention Oracle (the USA), which managed to secure the contract with the Federal Tax Service, Federal Treasury of the Ministry of Finance of the Russian Federation, Bank of Moscow, Rosgosstrakh (RGS), Ingosstrakh, industrial enterprises. Baan (the Netherlands) delivered software to major aviation enterprises of Russia, such as Komsomolsk-on-Amur Aircraft Plant (KnAAZ) and Irkut Corporation that manufacture military aircraft. The increasing number of the Russian enterprises and entities opt for foreign software based on the cloud technology, which means that the software is provided on the subscription basis as SaaS 
(Software as a Service) $)^{5}$ The technology is advantageous because users do not need to buy servers and other equipment where databases and software are stored. In this case, all the information about corporate performance is transferred to the provider's server, where it is finally processed. The software provider totally handles the process, while the customer just has its information processed and access to the software functions through the computer application. The customer has no access to the programs, being unable to modify it in any way, copy it, etc. Thus the software developer prevents the illegal distribution of software, while rendering the services to customers at relatively low cost. The provider of the cloud-based automated management system allows to switch off some idle functions or temporarily activates additional modules. This is an undeniable advantage of the technology from users' perspectives.

However, alongside the definite strengths of modern information technology and advantages for businesses and authorities, there is still an aspect that makes their broad use questionable. Third parties gain access to confidential information about the performance and operations of companies and governmental authorities that use the software. Customers of SaaS technology are exposed to the risk that they may lose control over their organizations. The classical case scenario implies that ERP users can replicate their files, edit the information on proprietary servers without notifying the provider. In the case of cloud technology, the provider solely grants access codes to users so that they could reach the data. However, such codes could be blocked at any point of time. Afterwards the provider may modify terms of contracts, transfer confidential information about its partners to third parties or make other actions putting customers' business at stake.

\footnotetext{
${ }^{5}$ Lenart A. ERP in the Cloud: Benefits and Challenges. In: Research in Systems Analysis and Design: Models and Methods. 4th SIGSAND/PLAIS 2011. Springer, 2011.

URL: https://doi.org/10.1007/978-3-642-25676-9_4
}

The use of foreign software engenders multiple threats, including the corporate data leakage and total disruption of its operation if any sanctions are imposed. Considering that foreign software developers mainly serve strategic enterprises in Russia, it is crucial to be especially prudent in choosing the software.

The State will make the national economy more resilient to external effects, if it urgently undertakes the import substitution initiative in IT. The import substitution program should provide for two steps (interim programs), i.e. software development (national ERP) and production of special hardware. There are national management automation programs in Russia. Being a brainchild of 1C and Galaktika Corporation, they can effectively substitute any foreign software ${ }^{6}$. Following the import substitution initiative in Russia, federal nuclear centers have already produced supercomputers that are capable of solving different tasks, including management of strategic production and enterprises. According to S.V. Kirienko, 117 supercomputers have already been supplied to strategic enterprises upon orders of the Ministry of Defense of the Russian Federation, Roscosmos Corporation, United Aircraft Corporation and nuclear sector.

It is noteworthy that the Russian law on State secrets applies to entities which not only directly deal with the military industry, but also are knowledgeable about reserves of mineral resources and promising research. Such information can be used for military purposes, infrastructure, corporate cooperation ties, some aspects of financial activity.

Russia is exposed to the risk that this sensitive information may become accessible or management systems get blocked. It is worth mentioning that any software or hardware failures makes users contact

\footnotetext{
${ }^{6}$ Vlasova L.G. Kontseptsiya prikladnogo resheniya '1C: ERP upravlenie predpriyatiem 2' [The concept of an applied solution 1C: ERP Corporate Management 2']. Moscow, 1C Pablishing Publ., 2016, 134 p.
} 
developers, which may manipulate users as they think fit.

It is important to note that the provider of software or hardware may download the information about open enterprises from time to time, analyze it and conclude on operations of the closed sectors of the economy subsequently.

Therefore, State-owned enterprises and public institutions should refrain from using foreign software provided there are domestically manufactured identical products.

It is especially vital for enterprises of strategic significance for the country, which deal with the development and production of armaments, military and space equipment. Restrictions should apply not only foreign software but also foreign computing, network and telecommunication equipment.

\section{Technological Threats in Manufacturing of Productive Means (Second Class Threats)}

Despite unique technologies and advanced pool of resources and technology, most Russia high-tech enterprises are losing their intellectual capital which they previously accumulated, thereby being unable to compete in the global market [4].

High value added products become less competitive since enterprises cannot manufacture components and assemblies of proper quality using their obsolete equipment. According to the Federal State Statistics Service of the Russian Federation, 50 percent of production equipment is obsolete, with the average age reaching twelve years ${ }^{7}$. Russia has been almost squeezed out of the global market of mechanical engineering, civil aircraft engineering. The Russian sectors of shipbuilding, aerospace engineering and others also demonstrate a technological lag [5].

\footnotetext{
${ }^{7}$ The average age and obsolescence of fixed assets in the process manufacturing sector. The Federal State Statistics Service of the Russian Federation. Russia in Figures. 2017. URL: http://www.gks.ru/wps/wcm/connect/rosstat_main/rosstat/ru/statist ics/enterprise/fund/\# (In Russ.)
}

The economic sovereignty of the State relies upon the creation of productive means, which include plant and equipment, i.e. highprecision and mixed-use machines, tools. The Russian industrial sector almost entirely depends on foreign supplies of high-precision machines and technological equipment. Currently, in Russia, the production of plant and equipment fell into decay (Table 1), though it is one of the necessary parts of the national technological independence strategy.

During the Soviet rule, equipment was almost entirely distributed among enterprises. This maintained the demand, which has become an important issue for market economies. The USSR made recurring attempts to replicate the best foreign specimens of equipment. This gave some results, but was still technologically outdated. Currently, the machine building sector tries to close the gap by providing preferential benefits to foreign direct investors in construction and retrofitting [6]. Enterprises with foreign shareholding have been set up and launched their production for the recent four years. These are the branch of DMG Mori Seiki (Germany and Japan) in Ulyanovsk, Guring in Nizhny Novgorod, MTE Kovosvit MAS in the Rostov-on-Don Oblast, etc. The governmental import substitution program helped reverse the negative trend and increase the output of machines and equipment in 2014 and onward. Enterprises secured licenses for producing the most advanced models of machines. Kovrov Electromechanical Plant mastered new machine assembly technologies of TAKISAWA. In Yekaterinburg, PumoriEngineering Invest launched the production line of the Japanese machining centers Okuma.

The State helped encourage the demand from enterprises embraced by federal specialpurpose programs. As a result, they have managed to increment the production output of machining equipment by 49 percent for 
three years. The output of numerical control machines almost doubled against 2013.

In the mean time, there are still pending issues in the domestic market. The Russian consumers still tend to buy necessary equipment abroad, even if they are offered identical products manufactured in Russia. They are demotivated with the low quality of domestic equipment, which is not quite true. The Russian machine building products are quite competitive, which is proved with the demand for the Russian equipment in global markets. According to the Federal Customs Service of the Russian Federation, Russian exports increased almost by onefourth in $2017\left(24,3 \%^{8}\right)$ against 2014. This proves the compliance of the Russian hightech products with the global technological level. However, the Russian manufacturing sector has not yet been able to eliminate the shortage of up-to-date high-precision and productive equipment, which defense, aviation and space enterprises seriously lack. Facing the shortage of mixed-used machines performing the maximum array of operations, programmable processing centers in the Russian market, consumers are seeking what they need abroad. The factor raises certain concerns since the prevalence of imported goods in the Russian market of plant and equipment threatens the national economic security.

As the analysis shows, the growth rate of import substantially exceeds that in the national production of machines and equipment. Hence, the Russian machine building enterprises were almost squeezed out of the national market by foreign competitors, notwithstanding import substitution efforts of the Russian Government. Whereas the Russian enterprises manufacture machines and equipment using foreign components, assemblies and devices, the total dependence of the Russian machine building sector on imports cannot be denied. The problem can be

\footnotetext{
${ }^{8}$ Customs statistics on foreign trade. Export and import of core commodities. URL: http://customs.ru:8111/index.php? option $=$ com_newsfts\&view $=$ category\&id $=53 \&$ Itemid $=1981$ (In Russ.)
}

solved to an extent if there are technological processes in place that require less machining. Such a trend originated long ago. However, the development of modern advanced technology proves their efficiency [7]. As various methods for manufacturing precise product blanks are invented, machining volumes decrease. The problem is that final machining is performed with high-precision and ultra-precision machines with its cost exceeding that of single-precision equipment ${ }^{9}$.

\section{Technological Threats Arising from Imports of Materials and Components (Third Class Threats)}

It is noteworthy that modern machines and equipment are fitted with management systems of various electronic devices, meters, memory units, which are usually produced abroad. The national machine building sector critically depends on imports of electronic devices. During the pre-crisis period (20072009) Russia faced the challenging situation when enterprises of the chemical and petrochemical industry, machine building and metal working sectors were unable to adequately perform without foreign materials, components and spare parts. As the analysis shows, in 2017, 53 percent of the machine building and metal working group of enterprises are totally dependent on imported products, at least, with respect to one item of technological products [8].

Properties and competitiveness of plant and equipment are determined from the quality of components, assemblies and constitutive elements [9]. The replacement of original components for domestic or foreign substitutes can dramatically influence the quality of ultimate products.

Modern models of electronic devices ensuring the operation of high-precision equipment

\footnotetext{
${ }^{9}$ Komkov A.E., Mironova M.O., Sokolova O.V. [Raising the quality of extremely thin-walled tubes manufactured with the cold rolling method]. Budushchee mashinostroeniya Rossii: materialy mezhdunaordnoi nauchnoi konferentsii [Proc. Int. Sci. Conf. The Future of Machine Building in Russia]. Moscow, Bauman Moscow State Technical University Publ., 2015, pp. 349-350. (In Russ.)
} 
significantly enhance qualities of national machine building products. However, Russia considerably lags behind its competitors in this sector. The Russian enterprises engineering plant and equipment have been referring to foreign electronic devices and other components in their projects for the recent three decades. Imports of such devices depend on external factors. For example, there is a special code in the USA (International Traffic in Arms Regulations ITAR). The code regulates the distribution of technologies that countries may use for military purposes. The economic sanctions, which were imposed in 2014 against Russia, prevent the proliferation of technologies, materials and components that can serve for dual purpose, thereby posing the threat to the modernization of the national economy. Currently, the sanction-based restrictions apply to dual-use equipment and materials only [10], which will do to manufacture military and civil machinery. However, the sanctions may embrace another types of activities and regions, thus menacing the innovative development of the Russian economy.

Implementing the import substitution program, Russia will ensure its independence from imports of foreign materials and components. There exists great opportunities for the development of radio electronics, since the demand significantly exceeds the supply of the Russian enterprises manufacturing electronic devises and electronic components. However, it should be noted that substantial financial injections will be needed in case of high-tech production start-ups, considering the limited access to technology. The Russian private investors are unable to bear such costs.

The State can support the radioelectronic industry by funding innovative development programs. In 2007, Russia launched the program, The Development of the Production of Electronic Components and
Radioelectronics for 2008-2015 ${ }^{10}$. The program pursues the recovery of the Russian enterprises that play a strategic role in the innovative development of Russia, its defensive capacity and competitiveness. The outcome of the program allowed to develop and manufacture a wide array of devices, including microprocessors and controllers, power electronics, radiationhardened microcircuits and other equipment which is just slightly inferior to foreign analogues.

The national program, the Development of Electronic and Radioelectronic Industry for 2013-2025 $5^{11}$, envisages the State aid to those enterprises that develop fundamental technologies for manufacturing priority electronic components and radioelectronic equipment. Furthermore, the State can refund some expenses for interests paid on loans that such enterprises obtained from the Russian credit institutions for the sectoral infrastructure projects, including radioelectronic clusters.

We should mention opinions of experts saying that the direct import substitution of electronic devices induces some predetermined lagging [11]. Virtually, specialists develop technologies or acquire licenses for manufacturing robust specimens of electronic devices that proved their usability abroad for several years. Considering that microcircuits double their productivity almost every two years ${ }^{12}$ [12], equipment fitted with outdated electronic devices will presumably become noncompetitive before it is launched in the market. While developing a technology and mastering new engineering products,

\footnotetext{
${ }^{10}$ Resolution of the RF Government On the Federal SpecialPurpose Program, The Development of the Production of Electronic Components and Radioelectronics, for 2008-2015, of November 26, 2007 № 809.

${ }^{11}$ Resolution of the RF Government On the Approval of the National Program, The Development of the Electronic and Radioelectronic Industries for 2013-2015, of December 2012 № 2396-p.

${ }^{12}$ Moore G.E. "No Exponential Is Forever: But 'Forever' Can Be Delayed!” Solid-State Circuits Conference, IEEE International Digest of Technical Papers, 2003, vol. 1, pp. 20-23.
} 
foreign manufacturers of electronic equipment can replace several generations of devices, which substantially differ from replicas. Constitutive components may happen to be taken out of the production. Hence, replicating will hardly solve the import substitution issue. To close the development gap, the Russian enterprises should seek results of promising research and develop their own technology respectively, rather than acquiring licenses for manufacturing successful specimens of equipment.

The State should especially try to lure foreign investors which bring advanced facilities for production of electronic devices and electronic components for broad new technologies. It is unreasonable to put resources into traditional technologies of microcircuit production due to the rapid succession of electronic generations. For example, electronic lithography cannot longer be used for electronic engineering technologies. The length of a light wave ranges from 380 to 780 nanometers and from 10 to 380 nanometers in the case of UV radiation. Therefore, the $14 \mathrm{~nm}$ technology appear to be quite outlived in terms of their further development. Considering the timelines for mastering the $14 \mathrm{~nm}$ technology at the Russian enterprises, the acquisition of licenses (if licensors agree to sell it) will unavoidably inhibit the development of the Russian radioelectronic industry. The resistless electron-beam litography is an alternative to optic litography. Such an enterprise was set up in Moscow under the license of Mapper Lithography Holding B.V. (the Netherlands). They run the technology of photoresist layer exposure with e-beam instead of light. What makes Mapper's technology more competitive is that it does not require expensive masks, which should be prepared for every type of microcircuits in the case of optical litography. Russia took part in Mapper Litography project as a contractor supplying electronic optical devices for ultra-miniature microcircuit production.
Technological threats may seriously damage the Russian economy. Therefore, the State should undertake appropriate measures to eliminate them.

In the long-run, it is necessary to focus on alternative approaches to developing microelectronics and computer equipment, which would rely upon absolutely new principles of data processing. Foreign countries actively carry out research and development for the creation of molecular (bio-) computers and processors based on optical, organic, quantum devices ${ }^{13}$. Enterprises should refrain from using materials and components of foreign suppliers that are vulnerable to the political situation in order to promptly address the current issues. Space and defensive equipment should be designed on the basis of the Russian electronic components, thus possibly lowering some operational properties but keeping the acceptable level of the economic security of strategic industries.

The import substitution program should be holistic, reducing the dependence on foreign partners, increasing the economic security and stimulating a growth and competitiveness of the Russian manufacturing sector.

The State is also unable to finance the replacement of all imported materials and components. The retrofitting of strategic manufacturing sectors, with the production of electronic components being a priority, should be financed so as to ensure the adequate level of independence in imports. Currently, this sector demonstrates the largest development lag with respect to almost all high-tech types of production. It is definitely unreasonable to forbid the import of all electronic components, including resistors, condensers and other components. They should be imported from various countries and manufactures that are mutually independent. As for radiation-hardened electronic components, network interface card, high-

\footnotetext{
${ }^{13}$ Minkin V.I. [Molecular computers]. Khimiya i zhizn' = Chemistry and Life, 2004, no. 2, pp. 13-17. (In Russ.)
} 
density microprocessors, enterprises should necessarily master new technologies, purchase the latest generation equipment, finance respective $R \& D$. The cost of the equipment manufactured for the Russian consumers can be reduced by expanding its practical scope. Products should actively circulate not only in the military and aerospace industries, but also in the civil sector of economy. Radiation-hardened and miniature electronic devices are used for $\mathrm{X}$-ray flaw detection, medical equipment, nuclear power engineering, scientific equipment, etc. This helps increase the output and ensure some saving effect due to the scale, thus reducing the price for products and capture a relatively large market share.

The import substitution program in IT can be successfully implement if enterprises master not only the production of modern computer equipment, but also raise the demand for it among the Russian and foreign consumers. Consumer equipment under the import substitution program should be compatible solely with the Russian management automation software and databases.

According to the classic economic theory, the dependence on imports can be tackled by stimulating the demand among enterprises and supply of the Russian manufacturers. The Russian enterprises can increase the output of science-intensive products only if they are significantly retrofitted and modernized. This will entail huge resources and time. Furthermore, production facilities should be technologically prepared for operations, which includes research and development, design, experimental and technological work. The designed equipment may become outdated during the above processes. Substantial costs and a long time span of the process make the modernization less lucrative and less feasible. In this scheme, the Russian enterprises are treated as copycats trying to catch up with industrially advanced economies.
According to some economists, the demand for the Russian software, hardware and electronic devices can be spurred by providing preferences to purchasers of the Russian products, i.e. tax breaks, contract for the performance of a State order [13], refund of interests on loans ${ }^{14}$. However, preferential loans do not always generate an expected effect since resources allocated for the technological development are used for property deals as part of mergers and acquisition, as E.S. Nabiullina says, the Chairperson of the Central Bank of Russia ${ }^{15}$.

We believe that finance and operating lease with the State aid is the most effective method to stimulate the demand. As seen in lease schemes, the enterprise obtains technological equipment for its production purposes and runs for a long-tem at a lower lease rate, including repair and scheduled maintenance throughout the entire period of a contract. Enterprises involved in the performance of the governmental procurement order for military purposes and federal special-purpose programs can be furnished with the Russian equipment by the State to offset future payments for products delivered under the contracts.

\section{Conclusion}

Technological threats can be eliminated by diversifying foreign suppliers of materials, components and equipment. We believe that it is unreasonable to deny imports of best-inclass equipment, materials and tools. However, entering into foreign trade and investment agreements, enterprises should be

\footnotetext{
${ }^{14}$ Zverev A.V., Sorokin A.A. [The interest rate policy of the Russian banks, its outcome and consequences for the current economic development]. Upravlenie sotsial'no-ekonomicheskimi sistemami i pravovye issledovaniya: teoriya, metodologiya $i$ praktika: materialy nauchnoi konferentsii [Proc. Sci. Conf. Management of Socio-Economic Systems and Legislative Studies: Theory, Methodology and Practice]. Bryansk, Bryansk State University Publ., 2017, pp. 137-144.

${ }^{15}$ Ts $B$ uzhestochit trebovaniya $k$ rezervam bankov pri kreditovanii sliyanii-pogloshchenii [The Central Bank of Russia will tighten bank reserve requirements in case of lending for M\&A].

URL: https://www.vedomosti.ru/finance/news/2018/02/01/749719 -uzhestochit-trebovaniya (In Russ.)
} 
certain that suppliers are free from any political pressure.

Basically, despite relatively high dependence on import, the Russian manufacturing sector can overwhelm this negative trend and reach the acceptable demand for the Russian equipment, thereby making the Russian economy more resilient to technological threats.

Table 1

Production of metal working machines in the Russian Federation, 1990-2016, units

\begin{tabular}{lllllllll}
\hline Analyzable item & $\mathbf{1 9 9 0}$ & $\mathbf{2 0 1 0}$ & $\mathbf{2 0 1 1}$ & $\mathbf{2 0 1 2}$ & $\mathbf{2 0 1 3}$ & $\mathbf{2 0 1 4}$ & $\mathbf{2 0 1 5}$ & $\mathbf{2 0 1 6}$ \\
\hline Metal cutting machines & 74,171 & 2,832 & 3,28 & 3,467 & 2,945 & 3,871 & 3,367 & 4,383 \\
\hline NC lathes & 18,056 & 129 & 195 & 166 & 137 & 227 & 204 & 337 \\
\hline
\end{tabular}

Source: Federal State Statistics Service of the Russian Federation

\section{References}

1. Leon A. Enterprise Resource Planning. New Dehli, McGraw-Hill, 2008, 500 p.

2. O'Leary D.E. Enterprise Resource Planning Systems: Systems, Life Cycle, Electronic Commerce and Risk. New York, NY, Cambridge University Press, 2000, 232 p.

3. Khrustalev E.Yu., Slavyanov A.S. [Decision making in the conditions of activation of external restraining factors with using of information model of the company]. Scientific Journal of KubSAU, 2016, no. 121(07). (In Russ.)

URL: http://ej.kubagro.ru/2016/07/pdf/42.pdf

4. Denisova A.L., Ulyakhin T.M. Upravlenie konkurentosposobnost'yu promyshlennogo predpriyatiya: aspekty kachestva [Management of the competitiveness of an industrial enterprise: Quality aspects]. Tambov, Tambov State Technical University Publ., 2006, $120 \mathrm{p}$.

5. Bat'kovskii A.M., Kalachanov V.D., Khrustalev E.Yu. [Analysis of innovative development of the Russian economy and military-industrial complex of the country]. Voprosy radioelektroniki, 2015, no. 5, pp. 204-221. (In Russ.)

6. Slavyanov A.S., Khrustalev E.Yu. [Tax mechanism to increase foreign investments effectiveness]. Ekonomicheskaya nauka sovremennoi Rossii $=$ Economics of Contemporary Russia, 2013, no. 1, pp. 72-81. (In Russ.)

7. Maretskaya V.V., Savel'eva L.V. [Issues of simulating technological process of parts manufacturing]. Glavnyi mekhanik = Chief Mechanical Engineer, 2015, no. 3, pp. 44-49. (In Russ.)

8. Makarov A.N. [Import dependence of industrial enterprises in the region as an economic security hazard]. Ekonomika regiona = Economy of Region, 2010, no. 4, pp. 121-124. (In Russ.)

9. Vasil'ev A.S. [Technological heredity in mechanical engineering]. Vestnik Rybinskoi gosudarstvennoi aviatsionnoi tekhnologicheskoi akademii im. P.A. Solov'eva = Vestnik of P.A. Solovyov Rybinsk State Aviation Technical University, 2017, no. 1, pp. 198-202. (In Russ.) 
10. Sokolov N.A., Larin S.N., Khrustalev E.Yu. [Quantitative evaluation of the impact of sanctions on the Russian economy in the short-term prospects]. Natsional'nye interesy: prioritety i bezopasnost' = National Interests: Priorities and Security, 2016, no. 8, pp. 44-54. URL: https://cyberleninka.ru/article/v/kolichestvennaya-otsenka-vliyaniyasanktsiy-na-rossiyskuyu-ekonomiku-v-kratkosrochnoy-perspektive (In Russ.)

11. Evseev V., Nalivkin E. [Electronic Components Base Import Substitution and Electronics Development. Problems Consideration]. Elektronika: nauka, tekhnologiya, biznes = Electronics: Science, Technology, Business, 2014, no. 8, pp. 156-162. (In Russ.)

12.Denning P.J., Lewis T.G. Exponential Laws of Computing Growth. Communications of the ACM, 2017, vol. 60, iss. 1, pp. 54-65. URL: https://doi.org/10.1145/2976758

13. Mitsek S.A., Mitsek E.B. [Russian economy in 2016: Outcomes, achievements and concerns]. Vestnik Gumanitarnogo universiteta $=$ Review of the Liberal Arts University, 2017, no. 3, pp. 6-24. (In Russ.)

\section{Conflict-of-interest notification}

We, the authors of this article, bindingly and explicitly declare of the partial and total lack of actual or potential conflict of interest with any other third party whatsoever, which may arise as a result of the publication of this article. This statement relates to the study, data collection and interpretation, writing and preparation of the article, and the decision to submit the manuscript for publication. 